УДК: 616.36/.367-06-089:616.36-008.5

DOI: 10.26697/ijes.2019.2.42

\section{Скільки повинна тривати біліарна декомпресія $y$ паціснтів із захворюваннями гепатикохоледоху за допомогою антеградних ендобіліарних втручань?}

Професор Свтушенко Д. О.

${ }^{1}$ Харківський національний медичний університет ${ }^{2}$ ДУ “Інститут загальної та невідкладної хірургії ім. В. Т. Зайцева НАМН Украӥни”, Украйна

${ }^{3}$ Український центр очінювання якості освіти

\section{Резюме}

Вступ:

Гіпербілірубінемія - невід'ємна ознака біліарної гіпертензії. Причиною обструкції жовчовивідних протоків стають як доброякісні, так і злоякісні захворювання гепатикохоледоху. Метою роботи $\epsilon$ визначення оптимальної тривалості черезшкірного черезпечінкового холангіодренування (ЧЧХД) в залежності від тривалості механічної жовтяниці (МЖ) та початкового рівня загального білірубіну сироватки крові у пацієнтів із доброякісними та злоякісними захворюваннями гепатикохоледоху, ускладненими МЖ.

\section{Методи:}

Згруповано досвід використання ЧЧХД у 88 пацієнтів із доброякісними та злоякісними захворюваннями гепатикохоледоху, ускладненими МЖ за період 2011-2017 pp. на базі кафедри хірургії № 1 Харківського національного медичного університету у клініці ДУ "Інститут загальної та невідкладної хірургії ім. В. Т. Зайцева НАМН України". Причинами МЖ були наступні захворювання: холедохолітіаз у 6 (6.8\%), стриктури гепатикохоледоху у $2(2.3 \%)$ та холангіокарциноми різної локалізації у 73 (82.9\%) пацієнтів. Пацієнти розподілені на три групи: першу (1) - склало 15 $(17.1 \%)$ пацієнтів із доброякісними захворюваннями гепатикохоледоху, другу (2) - 11 $(12.5 \%)$ пацієнтів із резектабельними холангіокарциномами та третю (3) - 62 (70.4\%) пацієнти із нерезектабельними холангіокарциномами. Тривалість холестазу визначали згідно з класифікацією Смирнова (1974). Гостра МЖ спостерігалася у 38 (43.2\%) пацієнтів, гостро тривала і хронічна МЖ спостерігалася у 11 $(12.5 \%)$ і 39 (44.3\%) пацієнтів відповідно. Пацієнти були розподілені по рівню загального білірубіну сироватки крові: 43-150 мкмоль/л -14 (15.9\%), 150250 мкмоль/л - 20 (22.7\%), 250-400 мкмоль/л - 28 $(31.8 \%)$ і більше 400 мкмоль/л - 26 (29.6\%) пацієнтів. 3 метою визначення оптимальних строків біліарної декомпресії за допомогою ЧЧХД, застосовано пуасонівський процес (poisson), а точніше як квазіпуасоновський розподіл (quasipoisson), який відображає процес зниження загального білірубіну сироватки крові. Останній відображає тривалість біліарної декомпресії, 3 урахуванням змінної - рівень білірубіну після дренування у часі, значення якої було пролагорифмовано: $\quad(\log ($ рівень $\quad$ загального білірубіну/тривалість холангіодренування).

\section{Результати:}

На основі проведеного аналізу було розраховано тривалість біліарної декомпресії, яка $\epsilon$ оптимальною для пацієнтів із доброякісними та злоякісними захворюваннями гепатикохоледоху, ускладненими МЖ за допомогою ЧЧХД, як пуасонівський процес, а точніше як квазіпуасоновський розподіл. Визначено, що найшвидше процес зниження загального білірубіну відбувається у пацієнтів 3 групи. Для таких пацієнтів достатньо у середньому 7-8 діб для зниження загального білірубіну до 50 мкмоль/л (загальний білірубін знижується у середньому на $13-14 \%$ за добу). У пацієнтів 1 групи процес відбувається дещо повільніше. Тривалість біліарної декомпресії у цієї категорії пацієнтів у середньому складає 10-12 діб (загальний білірубін знижується у середньому на $10 \%$ за добу). Для пацієнтів 2 групи на біліарну декомпресію потрібно не менше 12 діб (у середньому кожну добу показник білірубіну буде менше на 8\%, ніж у попередню).

\section{Висновки:}

За допомогою пуасонівського процесу (poisson), a точніше як квазіпуасоновського розподілу (quasipoisson), який відображає процес зниження загального білірубіну сироватки крові у часі, вдалося визначити оптимальну тривалість біліарної декомпресії за допомогою ЧЧХД в залежності від тривалості МЖ та початкового рівня загального білірубіну сироватки крові.

Інформація про авторів:

Бойко Валерій Володимирович - доктор медичних наук, професор, завідувач кафедри хірургії № 1, Харківський національний медичний університет; Директор ДУ “Інститут загальної та невідкладної хірургії ім. В. Т. Зайцева НАМН України"; https://orcid.org/0000-0002-3455-9705

Авдосьєв Юрій Володимирович - доктор медичних наук, професор, завідувач відділення інтервенційної радіології ДУ "Інститут загальної та невідкладної хірургії ім. В. Т. Зайцева НАМН України”; https://orcid.org/0000-0002-2677-4464.

Сочнсва Анастасія Львівна - аспірант, Харківський національний медичний університет; https://orcid.org/0000-0003-0106-5247.

Мазорчук Марія Сергіївна - кандидат технічних наук, методист відділу досліджень та аналітики, Український центр оцінювання якості освіти; https://orcid.org/0000-0002-4416-8361.

Свтушенко Денис Олександрович - доктор медичних наук, професор кафедри хірургії № 1, Харківського національного медичного університету; https://orcid.org/0000-0003-1941-7183. Наукові інтереси: хірургія, освіта, медичні науки.

Автор-Кореспондент:

Євтушенко Денис Олександрович

Email Автора-Кореспондента: dr.yevtushenko@ukr.net 